\title{
Stability of Mbuna Species Populations in Lake Malawi
}

Lucious G. Kanyumba ${ }^{1}$, Wisdom J. Changadeya ${ }^{1}$, Aggrey J.D. Ambali ${ }^{2}$, Leonard A. Kamwanja ${ }^{3}$ and Emmanuel K.W. Kaunda ${ }^{4}$

1. Department of Biology, University of Malawi, Zomba 280, Malawi

2. NEPAD Planning and Coordinating Agency, Pretoria 0184, South Africa

3. University Office, University of Malawi, Zomba 278, Malawi

4. Department of Aquaculture and Fisheries Science, University of Malawi, Lilongwe 219, Malawi

Received: April 21, 2011 / Accepted: November 11, 2011 / Published: April 20, 2012.

\begin{abstract}
The first comprehensive study of abundance, richness and distribution of Mbuna in Lake Malawi was carried out in the 1980s. The present study examined changes of species richness and abundance of Mbuna with time. Most sites demarcated during the 1980s survey were explored in order to determine changes in abundance and composition of Mbuna over a period of more than 20 years. Chi-square analysis revealed significant difference $(p<0.05)$ in abundance of Mbuna between 1983 and 2005 with the exception of Chinyankhwazi and Chinyamwezi where the difference was not significant $(p>0.05)$. Cluster analysis showed changes in species composition between 1983 and 2005 in various sites. Generally, there were more species lost in a given area than new species observed in 2005. Decline in Mbuna species richness might have been caused by siltation, harvesting of Mbuna for food and ornamental fish trade while new species were mostly introduced through translocation from one part of the lake to another.
\end{abstract}

Key words: Mbuna, species abundance, species richness, translocation.

\section{Introduction}

Lake Malawi is in the most southern basin of the Great African Rift Valley. With a north-south length of $600 \mathrm{~km}$ and maximum width of $75 \mathrm{~km}$, it is the third largest in Africa and the ninth in the world. The lake has surface area of about 28,000 $\mathrm{km}^{2}$, a maximum depth of $785 \mathrm{~m}$ and mean depth of $292 \mathrm{~m}$ [1]. It is renowned worldwide for its large number of species most of which are endemic. With over 700 species, it has the largest number and the most diverse communities of fresh water fish species in the world [2, 3]. Mbuna are the largest species flock restricted in the rocky habitats of less than $40 \mathrm{~m}$ depth. Speciation of Mbuna is mostly attributed to allopatry and sympatry through sexual selection [3].

Because of their sedentary habits, most of the Mbuna

Corresponding author: Wisdom J. Changadeya, senior lecturer, Ph.D., main research fields: fish population genetics, plant population genetics, biodiversity conservation. E-mail: wchanga@chanco.unima.mw, wisdomchangadeya@gmail.com. rarely migrate long distances from their locality. The resultant isolation of communities has created species endemic not only to the lake but to certain restricted areas within the lake itself. In turn, this aspect has led to adaptive speciation of fish species, which is said to be more diverse than of the Darwin finches of the Galapogas Islands [4].

The Government of Malawi through the Department of National Parks and Wildlife established the LMNP (Lake Malawi National Park) in 1980. It comprises of 13 islands, rocks and reefs located at the southern part of the lake in the districts of Mangochi and Salima (Fig. 1). The primary objective of establishing the park was to protect representatives of Lake Malawi's aquatic communities and their habitats with special reference to the rocky lakeshore and its specialist cichlid communities.

Malawi generally and the lakeshore areas in particular are experiencing ecological and environmental degradation because of a very dense and 


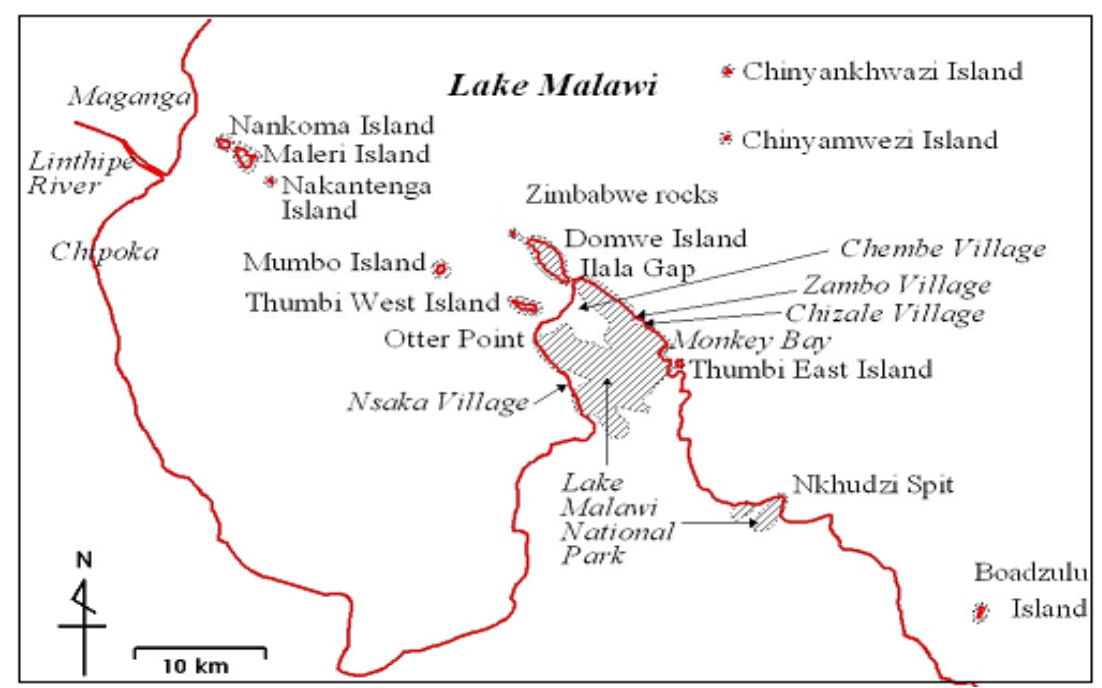

Fig. 1 Map of Lake Malawi National Park.

increasing human population whose livelihood depends on the utilisation of a limited and diminishing natural resource. Concern exists that the resource base of arable land, forests, wildlife and fish is threatened by unsustainable utilization which will lead to habitat damage by bottom dredging fishing gears, siltation caused by deforestation and farming, and depletion of fish stocks by over-fishing.

The most comprehensive study on rock dwelling fish (Mbuna) of Lake Malawi was a survey conducted by Ribbink et al. [5]. It provides an inventory and abundance descriptions of specific taxa of fish within the rocky areas of the lake. In terms of numerical abundance, the descriptions were not specific but gave ranges of numbers of individuals of fish that could be seen. The current study surveyed most of the sites that were covered by Ref. [5] in order to compare the status of species richness reported in 1983 to that of 2005 (this survey) so as to determine changes in species diversity and composition. The study also explored the degree to which sites have maintained their similarities in terms of species composition over a period of more than 20 years.

\section{Methods and Data}

\subsection{Sampling Sites}

Underwater observations with the aid of SCUBA diving were employed in studying Mbuna in Lake Malawi during the period August 2004-October 2005. SCUBA surveys were undertaken in the following areas: Chinyamwezi rock, Chinyankhwazi rock, Thumbi West Island (11 sites), Nkhudzi Spit, Kanchedza Island, Crocodile Rocks, Nkopola, and Boadzulu Island (4 sites) in the southern part of the lake; Mbenji Island (4 sites) in the central part of the lake; Kande (2 sites), Nkhata-Bay (2 sites), Chilumba (2 sites), Likoma Island (6 sites) and Chizumulu Island (3 sites) in the northern region of the lake (Fig. 2, Table 1). The same sites surveyed by Ribbink et al. [5] were studied, except in Chilumba where a new site was added (Table 1). Sites in southern and central Lake Malawi were sampled during the period August-November 2004 while the sites in northern region were surveyed during the period July-October 2005. No sampling was done during the rainy season due to turbidity which is high in the inshore waters.

\subsection{Fish Identification}

Prior to the underwater observation, a list of expected fish taxa at each site was compiled based on Ref. [5]. All special documented features of specific fish taxa such as body colour, size and shape, habitat type and depth preferred were compiled in advance to assist with identification during SCUBA diving, 
following Refs. [5, 6]. Although some of the species have subsequently been described, names used by Ref. [5] were used in order to facilitate comparison of species presence, abundance and richness between this study and Ref. [5].

\subsection{Fish Census Methods}

Line transects were used to record fish species and their abundance. A transect comprised of two poles with two holes drilled two meters apart connected with two ropes of $25 \mathrm{~m}$ length tied through the two holes. Each line transect covered an area of $2 \mathrm{~m} \times 25$ $\mathrm{m}\left(50 \mathrm{~m}^{2}\right)$. It was used in more or less uniform size bottom substratum offering a regular terrain where a uniform depth contour could be followed. Fish taxa and their abundance in transect were recorded by two

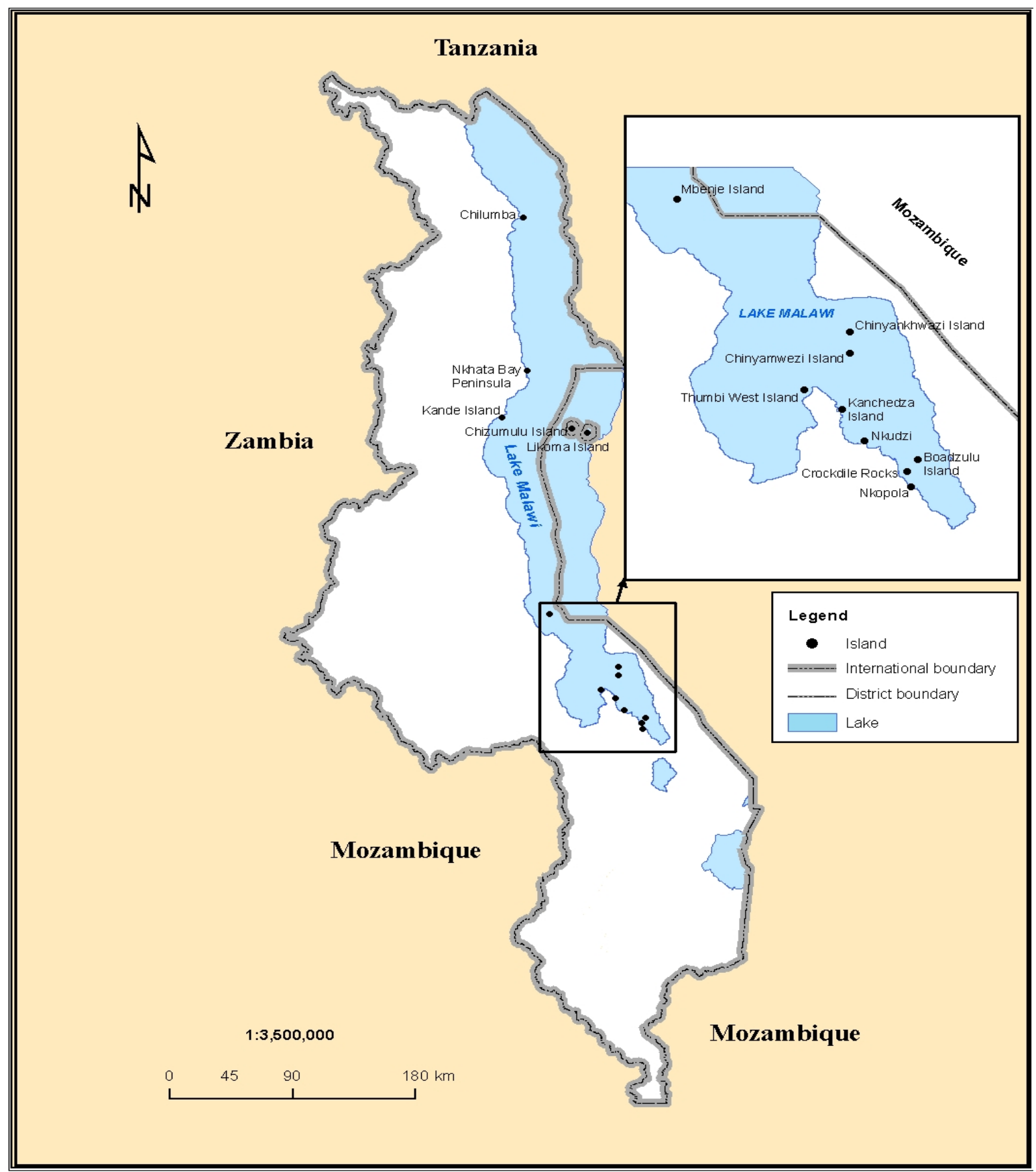

Fig. 2 Map of Malawi showing major sampling sites. 
Table 1 Sampling sites and their locations.

\begin{tabular}{|c|c|c|c|}
\hline Locations & Sampling sites & District & Region \\
\hline \multirow{11}{*}{ Thumbi West Island } & $\mathrm{A}$ & \multirow{6}{*}{ Mangochi } & \multirow{6}{*}{ South } \\
\hline & $\mathrm{B}$ & & \\
\hline & $\mathrm{B}+1$ & & \\
\hline & $\mathrm{C}$ & & \\
\hline & $\mathrm{C}+2$ & & \\
\hline & $\mathrm{D}$ & & \\
\hline & $\mathrm{E}$ & \multirow{5}{*}{ Mangochi } & \multirow{5}{*}{ South } \\
\hline & $\mathrm{E}+3$ & & \\
\hline & $E+4$ & & \\
\hline & $E+5$ & & \\
\hline & $\mathrm{F}$ & & \\
\hline \multirow{8}{*}{ South east Arm } & Kanchedza & \multirow{8}{*}{ Mangochi } & \multirow{8}{*}{ South } \\
\hline & Nkudzi & & \\
\hline & Crocodile rocks & & \\
\hline & Nkopola & & \\
\hline & Boadzulu-A & & \\
\hline & Boadzulu-B & & \\
\hline & Boadzulu-C & & \\
\hline & Boadzulu-D & & \\
\hline \multirow{2}{*}{$\begin{array}{l}\text { Chinyamwezi } \\
\text { Chinyankhwazi }\end{array}$} & One site & \multirow[t]{2}{*}{ Mangochi } & \multirow[t]{2}{*}{ South } \\
\hline & One site & & \\
\hline \multirow{4}{*}{ Mbenji Island } & A & \multirow{4}{*}{ Salima } & \multirow{4}{*}{ Centre } \\
\hline & $\mathrm{B}$ & & \\
\hline & $\mathrm{C}$ & & \\
\hline & $\mathrm{D}$ & & \\
\hline \multirow{2}{*}{ Nkhata Bay } & A & \multirow[t]{2}{*}{ Nkhata Bay } & \multirow[t]{2}{*}{ North } \\
\hline & B & & \\
\hline \multirow{2}{*}{ Kande } & $\mathrm{A}$ & \multirow[t]{2}{*}{ Nkhata Bay } & \multirow[t]{2}{*}{ North } \\
\hline & $\mathrm{B}$ & & \\
\hline \multirow{2}{*}{ Chilumba } & Mpanga rocks & \multirow[t]{2}{*}{ Nkhata Bay } & \multirow[t]{2}{*}{ North } \\
\hline & Chitande & & \\
\hline \multirow{6}{*}{ Likoma } & Membe & \multirow{6}{*}{ Likoma } & \multirow{6}{*}{ North } \\
\hline & Maingano & & \\
\hline & Mbako Point & & \\
\hline & Ndumbi rocks & & \\
\hline & Makulawe point & & \\
\hline & Masimbwe & & \\
\hline \multirow{3}{*}{ Chizumulu } & A-Mkanila Bay & & \\
\hline & B-Machili Islet & Likoma & North \\
\hline & C-Membe Islet & & \\
\hline
\end{tabular}

divers. Only areas sampled by Ribbink et al. [5] using line transects were sampled hence sites which required point transects were not covered during this survey so that data could be subjected to robust comparative statistical analyses.

In almost all the sites, except Kande and Croccodile rocks, transects were laid at six depths, namely $1 \mathrm{~m}, 3$ m, 5 m, 10 m, 15 m, and $20 \mathrm{~m}$. Sampling beyond 20 $m$ depth was not done for the safety of divers. Most Mbuna species are likely to have been encountered as they are restricted to the waters of 20-meter depth [5]. Sampling was done during the daytime and all sites 
were visited once. After setting transect lines, the fish were allowed to recover from the effect of diver disturbance and then counting was done. Data collected included name of species observed and number of individuals for each species.

\subsection{Data Analysis}

\subsubsection{Changes in Species Richness}

A study by Ribbink et al. [5] provides data on number of species observed at each of the six sampling depths covered in this survey for each of the sites. The number of species data for the 1983 survey was compared to that of 2005 (this study). This involved determining (i) the number of common species that were observed during both studies, (ii) number of species observed in 1983 only at a given site but not reported during the 2005 survey and (iii) number of species observed during the 2005 survey only but not reported by Ribbink et al. [5]. In addition number of species data at each of the depths was subjected to Chi-square analysis to determine if there was significant change in the species richness status during the two surveys. The Chi-Square test was carried out using the software STATISTICA [7]. This analysis was carried out on all the sites covered except Kande and Chilumba where Ribbink et al. [5] did not provide species count for Kande and for Mpanga Rocks at Chilumba.

2.4.2 Cluster Analysis-Time Comparison of Species Composition among Sites

Species presence-absence data was used to compare current study data (2005) to that of Ref. [5]. Species data was coded as either present (1) or absent (0) to create binary matrices, which were used to determine similarity of sites in a locality. The binary matrices were analysed with the computer program NTSYSpc version 2.11c [8]. Pairwise similarity matrices were computed using SM (simple matching) coefficient [9]. The similarity matrices were used to construct dendrograms from the SAHN (Sequential Agglomerative Hierarchical and Nested) clustering method using the UPGMA (Unweighted Pair-Group Method with Arithmetical averages) [10].

Bootstrap analysis, which is a method for determining confidence limits of clusters or groupings produced by UPGMA-based dendrograms, was performed using Win Boot program [11]. In order to obtain statistically accurate bootstrap $P$ values at 95\% level, 2,000 repetitive samplings of the data were performed for all dendrograms. SM which was the same coefficient used in NTSYSpc version 2.11 to construct dendrograms was used in the computation of the bootstraps [9]. The program used its own system clock to generate random number seed values to randomly sample the data matrix resulting in random data (bootstrap) matrices of the same size as the original matrix, which the program uses to produce dendrograms. The frequency with which a particular group (cluster) appears among all the dendrograms constructed provides an indication of the degree of support for that group. The frequency of occurrence of a particular cluster is given in percentages. In this case percentages are considered to be statistical tests (confidence limits) on the validity of the various clusters. The higher the percentage, the greater the confidence that a particular cluster is true, rather than being an artifact of the clustering process. The resultant bootstrap dendrograms were then combined into a majority-rule consensus tree to obtain an overall bootstrap estimate of the dendrogram [12].

The dendrograms were constructed on 1983 data [5] and also data from this survey. The sites included in this analysis were Thumbi West Island, Southeast arm sites, Mbenji Island and Likoma Island.

\section{Results}

\subsection{Species Richness}

The general trend was that there were more species observed in 1983 than in 2005. Summary of Chi-square analysis of species richness is provided in Table 2.

With the exception of Chinyankhwazi and Chinyamwezi, there was significant difference in the 
Table 2 Summary output of Chi-square analysis on the comparison between Ref. [5] and this study (2005) on number of Mbuna species observed at the various depths where transects were laid at each site.

\begin{tabular}{|c|c|c|c|c|}
\hline Site & $\begin{array}{l}\text { Sum number of } \\
\text { species } 1983\end{array}$ & $\begin{array}{l}\text { Sum number of } \\
\text { species } 2005\end{array}$ & $\begin{array}{l}\text { Chi-square } \\
\text { value }\end{array}$ & $p$-value \\
\hline Thumbi West Island & 577 & 549 & 25.51 & 0.0001 \\
\hline \multicolumn{5}{|l|}{ Southeast arm } \\
\hline Chinyankhwazi \& Chinyamwezi & 103 & 84 & 9.5 & 0.090 \\
\hline Mbenji Island & 101 & 71 & 19.18 & 0.001 \\
\hline Nkhata-Bay & 199 & 159 & 13.99 & 0.015 \\
\hline Likoma Island & 518 & 474 & 24.75 & 0.000 \\
\hline Chizumulu Island & 298 & 270 & 59.55 & 0.000 \\
\hline
\end{tabular}

number of species observed in 1983 and 2005 at the various depths between sites $(p<0.05)$.

The comparison of Mbuna species observed in 1983 to that of 2005 is provided in Table 3 and the listing of actual species missing or gained in 2005 are provided in Table 4. The general trend was that there were more species missing in the 2005 survey than those newly reported but not observed by Ref. [5]. A remarkable decline in the number of species was reported at Nkhata-Bay and yet no new species were reported in the two sites sampled (Table 4).

\subsection{Similarities of Thumbi West Island Sites}

Dendrograms of similarities on sites at Thumbi West Island are presented in Fig. 3. In 1983, sites C and D shared $89 \%$ of the species while sites A and B shared $85 \%$ of the species. Site $\mathrm{F}$ shared $83 \%$ of its species with A, B, C and D. The most outgroup site was E which shared $78 \%$ of the species with the rest of the sites. A noticeable change in species composition was observed in this study where $\mathrm{C}$ and $\mathrm{E}$ shared the highest number of species (85\%), followed by sites B and D,
$81 \%$. Site A is only sharing $75 \%$ of its species with B and D, while Site F is an outgroup. This suggests that considerable changes in species composition between sites have taken place at Thumbi West Island. An additional species $P$. tropheops "gold otter" was recorded on the island which was not observed by Ribbink et al. [5]. The bootstrap values for the 1983 cluster are generally higher than those of the 2005 cluster.

\subsection{Similarities of Southeast Arm Sites}

Similarity dendrograms for Southeast arm sites are presented in Fig. 4. Relatively minor changes in species composition were depicted in Southeast arm compared to Thumbi West Island (Fig. 3). In 1983, Crocodile Rocks shared $86 \%$ of the species with Nkopola while Kancheza shared $84 \%$ of the species with Nkudzi. Boadzulu emerged as an outgroup. In the 2005 survey, Kanchedza and Nkudzi had a major shift in species composition, the two sites clustered with very low bootstrap value compared to 1983. On the other hand, the species composition at Crocodile Rocks and

Table 3 Comparison of Mbuna species observed in 1983 and those observed in 2005.

\begin{tabular}{llll}
\hline Site & \multicolumn{2}{l}{$\begin{array}{l}\text { Number of species observed Number of species } \\
\text { in } 1983 \text { and 2005 }\end{array}$} & $\begin{array}{l}\text { Number of species observed in } \\
\text { observed in 1983 only }\end{array}$ \\
\hline Thumbi West Island & 40 & 4 & 1 \\
Southeast arm & 26 & 2 & 2 \\
Chinyankhwazi \& Chinyamwezi & 14 & 3 & 0 \\
Mbenji Island & 25 & 4 & 0 \\
Nkhata-Bay & 23 & 10 & 0 \\
Likoma Island & 34 & 5 & 1 \\
Chizumulu Island & 25 & 3 & 2 \\
\hline
\end{tabular}


Table 4 List of Mbuna species observed in 1983 only and those observed in 2005 only.

\begin{tabular}{|c|c|c|}
\hline Site & Species observed in 1983 only & Species observed in 2005 only \\
\hline Thumbi West Island & $\begin{array}{l}\text { Pseudotropheus aurora } \\
\text { P. livingstonii "likoma" } \\
\text { P. socolofi } \\
\text { Cyanthochromis obliquidens }\end{array}$ & P. tropheops "gold otter" \\
\hline Southeast arm & $\begin{array}{l}\text { P. zebra "fusco" } \\
\text { P. tropheops boadzulu }\end{array}$ & $\begin{array}{l}\text { P. zebra manzizi } \\
\text { Melanochromis blotch }\end{array}$ \\
\hline $\begin{array}{l}\text { Chinyankhwazi \& } \\
\text { Chinyamwezi }\end{array}$ & $\begin{array}{l}\text { Melanochromis crabo } \\
\text { M. cf brevis } \\
\text { M. brown }\end{array}$ & \\
\hline Mbenji Island & $\begin{array}{l}\text { P. zebra fusco } \\
\text { P. williamsi “mbenji" } \\
\text { P. lucerna "mbenji” } \\
\text { M. crabo }\end{array}$ & \\
\hline Nkhata-Bay & $\begin{array}{l}\text { P. tropheops "mauve" } \\
\text { P.t. "rust" } \\
\text { P.t. "deep" } \\
\text { P.t. "band" } \\
\text { P.t. "no band" } \\
\text { P. elongates "nkhata brown" } \\
\text { P. lucerna } \\
\text { P. minutus } \\
\text { M. crabo } \\
\text { Petrotilapia "small blue" }\end{array}$ & \\
\hline Likoma Island & $\begin{array}{l}\text { Melanochromis "blue" } \\
\text { M. lobrosus } \\
\text { Labidochromis zebroides } \\
\text { Cyanotilapia "ndumbi" }\end{array}$ & P. zebra cobalt \\
\hline Chizumulu Island & $\begin{array}{l}\text { Petrotilapia retrognatus } \\
P . \text { "yellow ventral” } \\
\text { Genyochromis mento }\end{array}$ & $\begin{array}{l}\text { Pseudotropheus "thin stripe" } \\
\text { Labidochromis zebroides }\end{array}$ \\
\hline
\end{tabular}

Nkopola remained high but lower by about 3\%. Boadzulu Island still remained an outgroup in the area.

The clustering of 1983 populations is stronger than that of 2005 as demonstrated by high bootstrap values.

\subsection{Similarities of Mbenji Island Sites}

There was no change in the clustering of sites on Mbenji Island between 1983 and 2005 surveys. Site A shares $97 \%$ of its species with Site C. Site B is an outgroup on the island. The pattern is maintained in 2005 although the level of similarity between A and C is lower (86\%). The bootstrap value for the arm separating B from the other three sites is weaker than that of 2005 (Fig. 5).

\subsection{Similarities of Likoma Island Sites}

In 1983, there were two main clusters of sites on the Island where Membe, Maingano and Mbako sites cluster together while the other three sites formed a second cluster. The two clusters separated with high bootstrap values. In 2005, the pattern changed, Mkulawe site clustered with Mbako forming a sub-branch of one major cluster while Ndumbi and Masimbwe formed a second major cluster. The bootstrap values for the two major clusters were weaker than those of the 1983 dendrogram (Fig. 6).

\section{Discussion}

A change in species richness of Mbuna was observed during the 22 year period both in protected and unprotected areas, although almost all the sites still maintained at least $70 \%$ of the species that were reported in 1983. The highest retention of species was observed in the protected areas although not significantly different from unprotected areas $(p>$ 0.05). 


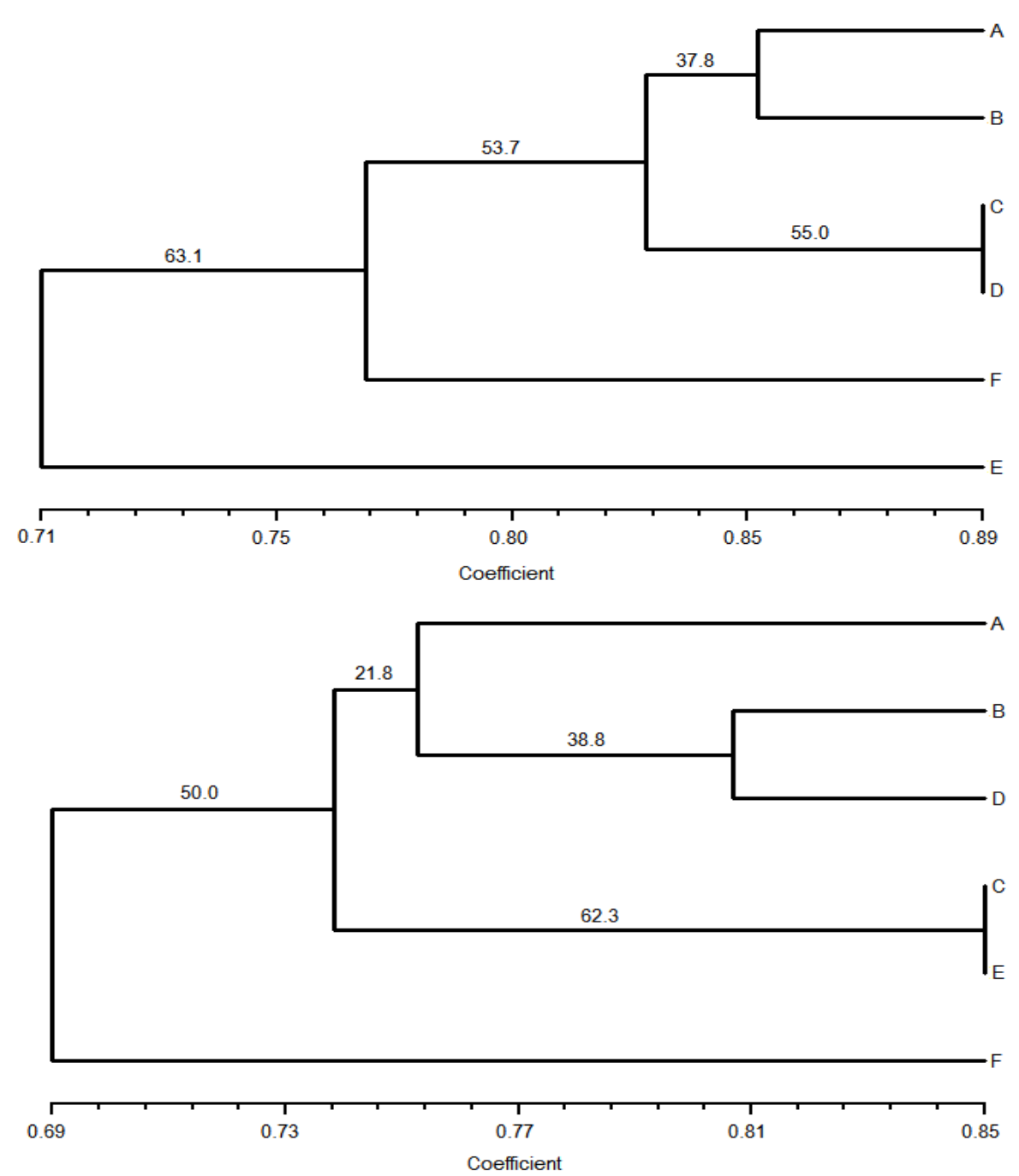

Fig. 3 Dendrograms of similarities between Thumbi West Island sites in terms of species composition.

Top dendrogram is for Ref. [5] data while the bottom dendrogram is for 2005 data (this study); values at each node represent the bootstrap values.

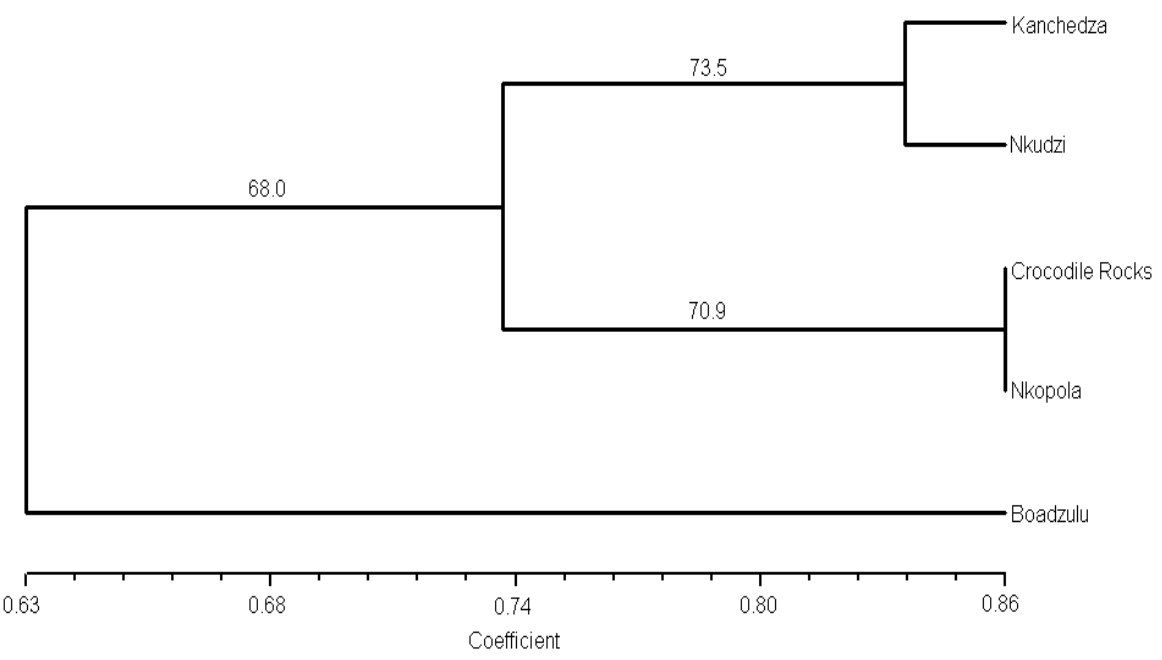




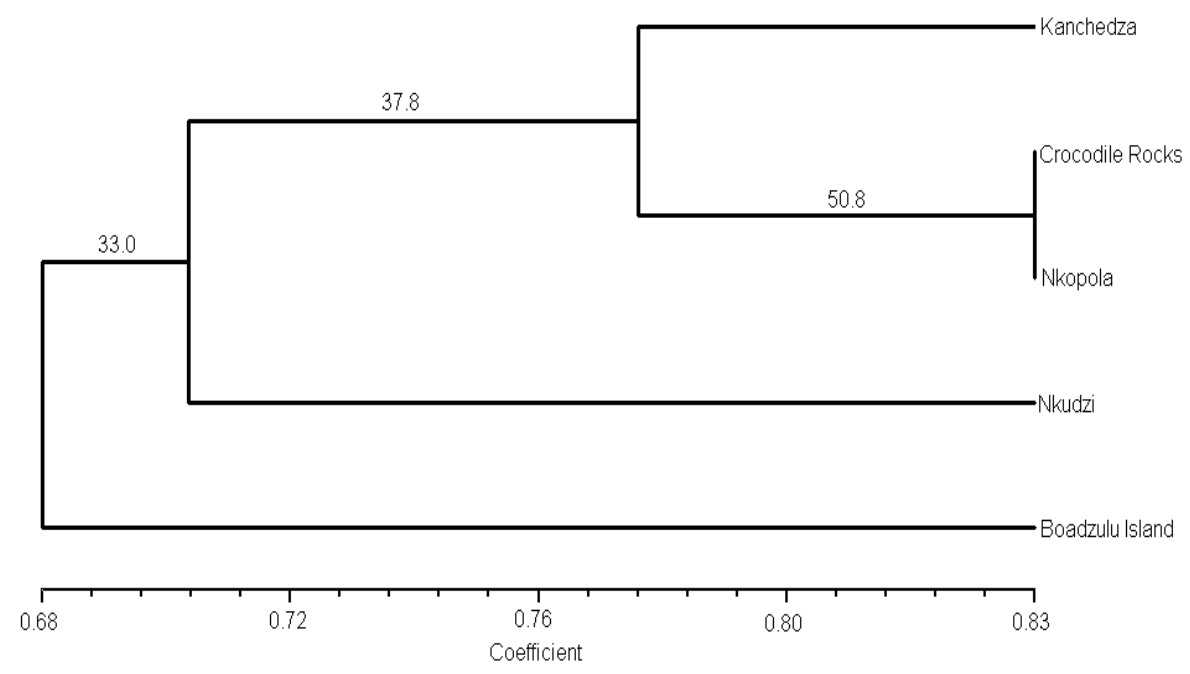

Fig. 4 Dendrograms of similarities between Southeast Arm sites in terms of species composition.

Top dendrogram is for Ref. [5] data while the bottom dendrogram is for 2005 data (this study).
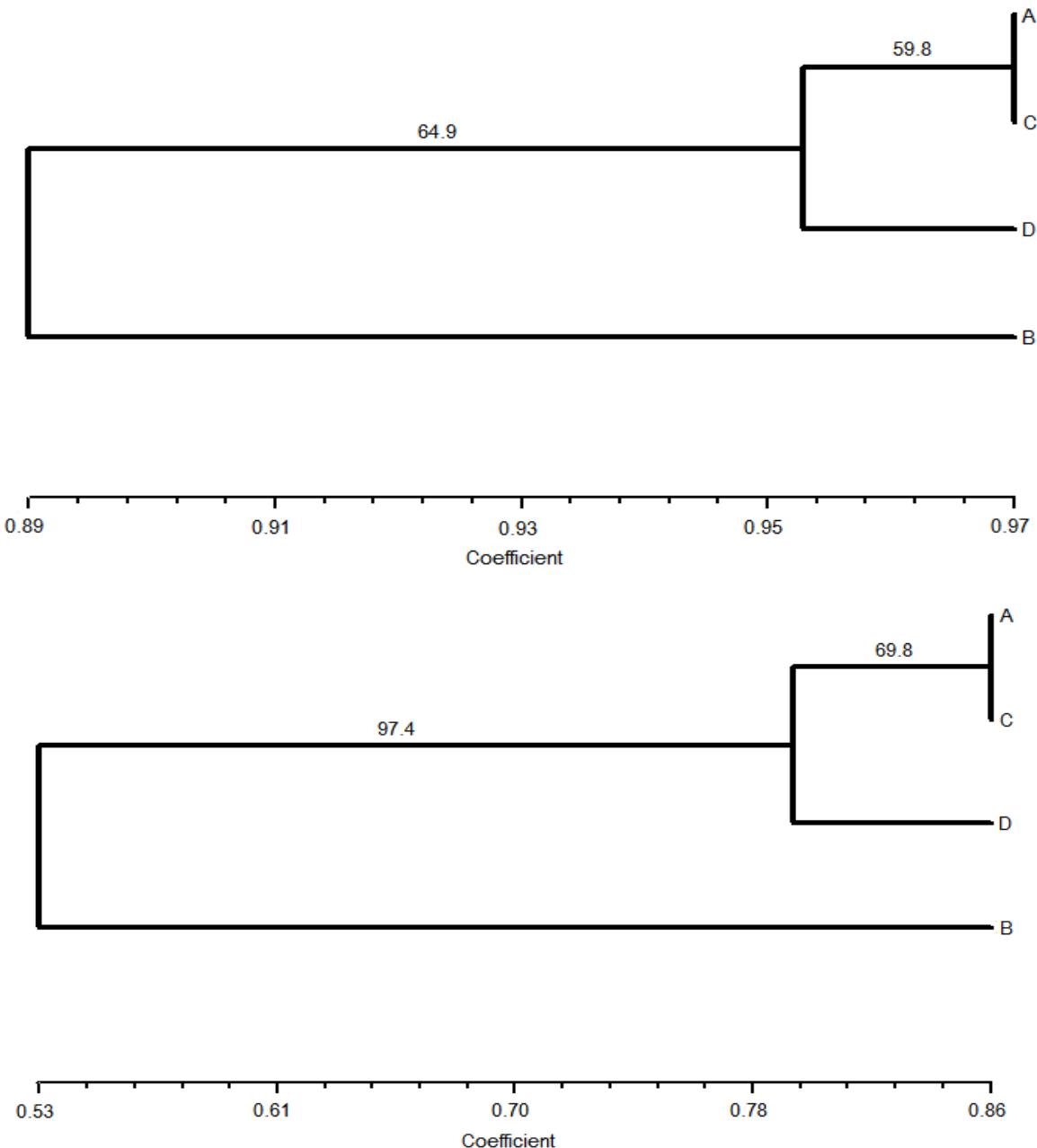

Fig. 5 Dendrograms of similarities between Mbenji Island sites in terms of species composition.

Top dendogram is for Ref. [5] data while the bottom dendrogram is for 2005 data (this study); values on the branches are bootstrap values. 

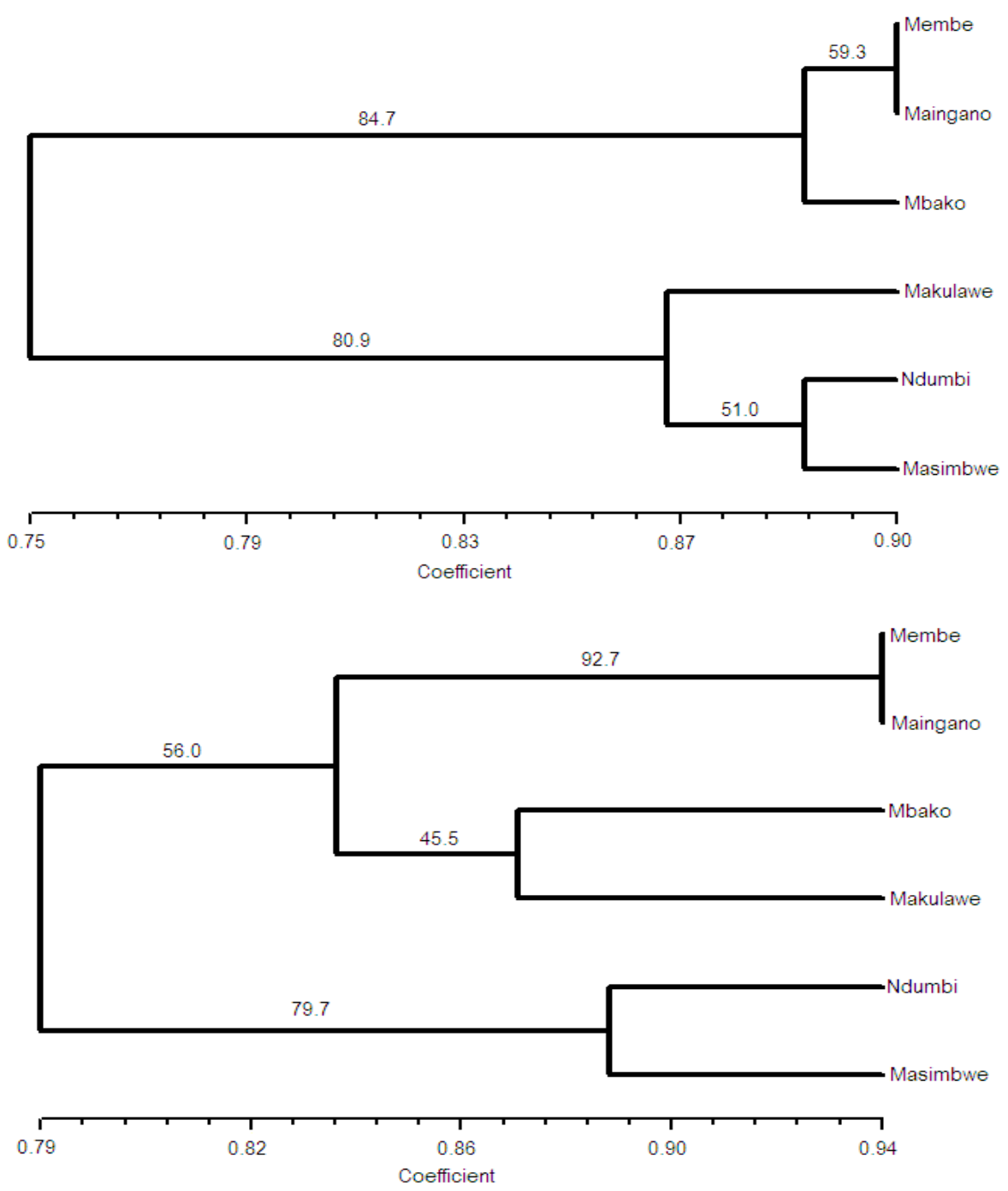

Fig. 6 Dendrograms of similarities between Likoma Island sites in terms of species composition.

Top dendrogram is for Ref. [5] data while the bottom dendrogram is for 2005 data (this study); values on the branches are bootstrap values.

The highest species losses were reported in Nkhata-Bay (30\%) followed by most of the islands outside or far away from the Lake Malawi National Park offices at Cape Maclear, which range from 10\% to $17.6 \%$. One of major threats to species diversity and abundance of Mbuna is catching Mbuna for food either as by-catch of such gears as "chilimira” (Off-shore seine net) or direct catch for food by fishermen who camp on the islands. These have special gillnet that uses to catch Mbuna for food while on the islands. A practice observed is that the fishermen save "utaka" (Copadichromis spp) and other prime fish species for sale while they themselves subsist on Mbuna. Decline in species diversity and abundance was observed on Mbenji Island site B, while Ribbink et al. [5] recorded 29 species but this survey found only five species recorded by Ribbink et al. [5] in low densities.

Mbuna are known to have highly localized distributions, yet studies carried out on different parts of the lake have been reporting additional species which were not reported by Ribbink et al. [5]. For instance, Genner et al. [13] reported that since 1996, 12 Mbuna taxa have been reported in Nkhata-Bay that were absent from the previous surveys. These have not 
been recruited as a result of migration but they have been translocated from the eastern or north-western shores of Lake Malawi as ornamental fishes. Of the 12 species, 11 were new to the area (Table 5). Cases of ornamental fish trade operators relocating Mbuna from one side of the lake have been reported in other areas as well. In 1960s, an aquarium fish trader based at Cape Maclear introduced roughly 20 cichlid species from northern Lake Malawi to a single site (Mitande) at
Thumbi west Island [5, 14] (see Table 6 for introduced Mbuna). One of such species is Cyanotilapia afra which was confined to Mitande point but during the 1990s it was reported to have hybridized with the native Metriaclima zebra [15]. Microsatellite DNA analysis confirmed this observation by showing that the admixture proportions were significantly different from northern versus southern populations separated by less than $1 \mathrm{~km}$ [14].

Table 5 Introduced Mbuna species and year first observed in Nkhata-Bay.

\begin{tabular}{llc}
\hline Translocated species & Inferred source site & Year first observed \\
\hline Cynotilapia afra & Cobue, Mozambique & 2004 \\
Cynotilapia “mbweca” & Cobue, Mozambique & 2004 \\
Cynotilapia "lion” & Lions Cove, Malawi & 1997 \\
Cynotilapia pulpican & Likoma Island, Malawi & 2004 \\
Melanochromis interruptus & Chizumulu Island, Malawi & 1996 \\
Melanochromis joanjohnsonae & Likoma Island, Malawi & 2004 \\
Pseudotropheus “daktari” & Southern Tanzania & 2004 \\
Psuedotropheus “elongatus chewere” & Chewere, Malawi & 2004 \\
Pseudotropheus “elongatus ornatus” & Likoma or Chizumulu Island & 2002 \\
Pseudotropheus aurora & Likoma Island & 1997 \\
Pseudotropheus hajomaylandi & Likoma Island & 2004 \\
Pseudotropheus "hajomaylandi Cobue” & Cobue, Mozambique & 2004 \\
\hline
\end{tabular}

Source: adapted from Ref. [13].

Table 6 Introduced Mbuna species of Lake Malawi National Park.

\section{Cynotilapia afra}

Labeotropheus fuelleborni "yellow flank"

Labidochromis freibergi

Labidochromis gigas

Melanochromis sp. "black-white johanni"

Melanochromis joanjohnsonae

Melanochromis parallelus

Melanochromis "red"

Pseudotropheus aurora

Pseudotropheus livingstoni "Likoma”

Pseudotropheus zebra "cobalt"

Source: adapted from Ref. [16].

\subsection{Potential for Sustaining Harvesting of Mbuna for Ornamental Fish Trade}

The fact that species diversity of Mbuna is still high in both protected and non-protected areas suggests that ornamental fish trade may not be harvesting the rock-dwelling Mbuna in excess of their maximum sustainable yields [17]. This is probably because Mbuna have high degree of endemism and catches by the aquarium trade operators is selective. That is, Mbuna are being caught in several places depending on their area of endemity. Considering the fact that ornamental fish trade is selective in the species that are collected for export and that the business has so far not led to considerable depletion of stocks and species, it would be advisable to integrate the trade in the conservation process of the Mbuna.

\subsection{The Effect of Mbuna Translocation}

Studies of translocated Mbuna at Thumbi West Island have had several revelations as to the population dynamics between introduced and indigenous species as follows: (i) with increasing depth there has been 
significant decrease in the number of indigenous species but not in the number of translocated species; (ii) significant increase in the total number of species between 1983 and 1998-1999 but no change in the number of indigenous species; (iii) with increased depth, there was significant decline in the number of territorial males and number of males of indigenous species but no change in the number of males of translocated species; (iv) significant increases between 1983 and 1998-1999 in total number of territorial males of translocated species but no change in the number of males of translocated species [13]; (v) in 2001 C. afra had colonized the entire Thumbi Island from Mitande point where it was introduced and in two decade it has diverged into genetically distinct, phenotypically different northern and southern populations; (vi) there was a high proportion of hybrids between the introduced C. afra and the native Pseudotropheus zebra on the northern coast of Thumbi West hence there is introgression between translocated and indigenous taxa [14]. Based on all these consequencies, it is likely that translocated species will establish themselves in these new sites.

\section{Conclusions}

This paper has revealed several pointers with regards to the status of Mbuna in Lake Malawi. The general trend is that in most of the areas of the lake, Mbuna species richness is on the decline as evidenced by some species missing during the 2005 study which were in fact reported in 1983. There are however exceptions to this trend especially in the Lake Malawi National Park and Nkhata-Bay where there were additional species reported either in this study or others cited herein due to introductions made by ornamental fish trade operators. The species composition has also changed over the period as is portrayed by differences in the clustering patterns between sites in 1983 and 2005.

Several factors have contributed to the changes in species composition and richness. These include exploitation of Mbuna for food by fishermen and ornamental fish. With decline in the catches of "food" fish there has been intensive pressure of Mbuna which generally are not considered "food" fish.

The ornamental fish trade has two effects on Mbuna populations, namely depletion of species of high demand and translocation of species from one part of the lake to another. The practice of translocating fish has gone unnoticed in most parts of the lake, but in areas where these have been noticed there is a change in species composition and in some cases in the densities of Mbuna. There have so far been limited studies, if any, that have attempted to quantify the extent of Mbuna depletion attributable to ornamental fish traders in Lake Malawi.

\section{References}

[1] G. Patterson, O. Kachinjika, Limnology and phytoplankton ecology, in: A. Menz (Ed.), The Fishery Potential and Productivity of the Pelagic Zone of Lake Malawi/Nyasa, Chatham, Natural Resources Institute, UK, 1995, pp. 1-67.

[2] G.F. Turner, Offshore Cichlids of Lake Malawi, Cichlid Press, Lauenau, 1996, p. 240.

[3] D. Kassam, S. Seki, B. Rusuwa, A.J.D. Ambali, K. Yamaoka, Genetic diversity within the genus Cynotilapia and its phylogenetic position among Lake Malawi's Mbuna cichlids, African Journal of Biotechnology 4 (10) (2005) 1195-1202.

[4] A. Meyer, T.D. Kocher, P. Basasibwaki, A.C. Wilson, Monophyleticorigin of Lake Victoria cichlid fishes suggested by mitochondrial DNA sequence, Nature 347 (1990) 550-553.

[5] A.J. Ribbink, B.A. Marsh, A.C. Ribbink, B.J. Sharp, A preliminary survey of the cichlid fishes of the rocky habitats of Lake Malawi, South African Journal of Zoology 18 (1983) 155-309.

[6] A. Konings, Konings Book of Cichlids and All Other Fishes of Lake Malawi, T.F.H. Publications, 1990, p. 495.

[7] StatSoft Statistica, Version 8, StatSoft Inc, Tulsa OK 74104, USA, 2007.

[8] F.J. Rohlf, NTSYS-pc, Numerical Taxonomy and Multivariate Analysis System, Exeter Software, Setauket, NY, 1993.

[9] R.R. Sokal, C.D. Michener, A statistical method for evaluating systematic relationships, University of Kansas Science Bull. 38 (1958) 1409-1438.

[10] P.H.A. Sneath, R.R. Sokal, Numerical Taxonomy, Freeman, San Francisco, 1973, p. 573. 
[11] I.V. Yap, R.J. Nelson, WinBOOT: A Program for Performing Bootstrap Analysis of Binary Data to Determine the Confidence Limits of UPGMA-Based Dendrograms, International Rice Research Institute (IRRI), Philippines, 1996.

[12] J. Felsenstein, Confidence limits on phylogenies: An approach using the bootstrap, Evolution 39 (1985) 783-791.

[13] M.J. Genner, A. Botha, G.F. Turner, Translocation of rocky habitat cichlid fishes to Nkhata-Bay, Lake Malawi, Journal of Fish Biology 69 (2006) 622-628.

[14] J.T. Streelman, S.L. Gmyrek, M.R. Kidd, C. Kidd, R.L. Robinson, E. Hert, et al., Hybridization and contemporary evolution in an introduced cichlid fish from
Lake Malawi National Park, Molecular Ecology 13 (2004) 2471-2479.

[15] J.R. Stauffer Jr, N.J. Bowers, T.D. Kocher, K.R. McKaye, Evidence of hybridization between Cynotilapia afra and Pseudotropheus zebra (Teleostei: Cichlidae) following an intralacustrine translocation in Lake Malawi, Copeia (1996) 203-208.

[16] S.A. Grenfell, Lake Malawi National Park Management and Development Plan, Department of National Parks and Wildlife, Lilongwe, 1993, p. 64.

[17] A. Ambali, H. Kabwazi, L. Malekano, G. Mwale, D. Chimwaza, J. Ingainga, et al., Relationship between local and scientific names of fishes in Lake Malawi/Nyassa, African Studies Monograph 22 (3) (2001) 123-154. 